\title{
CORRESPONDENCE
}

\section{Comment on late Precambrian palaeoclimates}

SIR - I wish to comment briefly on M. J. Hambrey's (1983, pp. 226-7) discussion of late Precambrian palaeoclimates and thereby clear up any misunderstandings concerning my views on late Precambrian conditions in relation to the high-obliquity model of low-latitude glaciation (Williams, 1975).

Hambrey misinterprets my remarks on ice-wedge pseudomorphs. I did not imply that such structures merely indicate seasonally low temperatures; comparison was made with structures formed in the upper part of modern permafrost horizons. I regarded the ice-wedge structures as indicating a seasonal climate comparable to that of modern polar periglacial regions. In such regions, notwithstanding negative mean annual air temperatures, summer air and uppermost ground temperatures typically rise above freezing. Fossil ice-wedge structures indicate both harsh periglacial conditions and significant seasonality.

The tillite-dolostone-redbed association remains controversial, particularly as to whether the aphanitic dolostones accumulated in warm or cold waters. I favoured a warm-water origin, concluding that the interbedding of tillites with dolostones and iron-rich facies may reflect Milankovitch-type fluctuations in insolation perhaps $10^{4}$ to $10^{6} \mathrm{yrs}$ in duration, that is, interglacials. As I pointed out (Williams, 1975), the weak to moderate climatic zonation that would prevail with a high obliquity of the ecliptic might well allow exaggerated oscillations of local climate in response to such insolation changes. The picture I wished to convey, therefore, was of delicately balanced, unstable local climates and climatic boundaries on a weakly zoned globe, not of permafrost, glaciers, and warm seas all within the same area at the same time!

My explanation of the tillite-dolostone-redbed association is, however, best regarded as a corollary of the high-obliquity hypothesis; other explanations of such facies associations are possible. The two principal arguments for an increased obliquity of the ecliptic in late Precambrian time are (1) the apparent preference of ice sheets to form in low to moderate palaeolatitudes, and (2) the evidence for strong seasonality, particularly with regard to temperature, as demonstrated by the occurrence of glacial varves and periglacial ice-wedge structures in low palaeolatitudes. Both arguments are dependent ultimately on accurate palaeomagnetic determinations of palaeolatitude.

\section{References}

Hambrey, M.J. 1983. Correlation of Late Proterozoic tillites in the North Atlantic region and Europe. Geological Magazine 120, 209-32.

Williams, G. E. 1975. Late Precambrian glacial climate and the Earth's obliquity. Geological Magazine 112, 441-65.

\section{G. E. WILLIAMS}

BHP Exploration Department

GPO Box 1818, Adelaide

South Australia 5001

Australia

19th August 1983
SIR - I welcome Dr Williams's comments on my paper on Late Precambrian tillites (Hambrey, 1983). I apologize to him for misinterpreting his remarks of fossil periglacial features. This arose by taking out of context his sentence 'Ice sheets and permafrost accordingly can be envisaged principally in low and middle latitudes with contiguous warm-water and iron-rich facies under a markedly seasonal climate'.

Both of us refer to these periglacial structures as 'ice-wedge pseudomorphs'. Chumakov (1968), who first described them from Spitsbergen, attributed this pseudomorph origin for them. Spencer (1971), who examined similar features in the Port Askaig Tillite of western Scotland also considered, amongst other possibilities, whether they were ice-wedge pseudomorphs. However, he rejected this explanation and believes (personal communication, June 1983) that it is sedimentologically impossible for pseudomorphs of icewedges to form; I regret I implied otherwise (p. 219). Instead Spencer proposed (1971) that the feature formed by wind-blown sand filling frost-contraction cracks as, for example, in the arid parts of Antarctica today.

The common association of tillites with dolostones, and the frequent occurrence of red coloration in Late Proterozoic sediments, is still an intriguing problem. Most of us working on these problems have tended to speculate that carbonates are deposited, and reddening takes place, under particular climatic conditions, e.g. that dolostones form in warm water (e.g. Schermerhorn, 1974 and Williams, 1975) or even cold water (e.g. Hambrey, 1982); also that reddening reflects weathering under a warm (possibly interglacial) climate (Williams, 1975; Harland \& Herod, 1975; Hambrey, 1982). Continuing work on the well-preserved Ny Friesland (Spitsbergen) sequence by Dr Ian Fairchild and myself is revealing a more complex picture. Petrographic studies of the carbonates within the glacial units indicate a clastic origin, whereby glacial grinding produces a rock flour of dolomite (Fairchild, 1983). By contrast the carbonate-rich units above and below contain a variety of warm water indicators, e.g. evaporite pseudomorphs. Climatic changes, then, do appear to be marked in Late Precambrian time (Fairchild \& Hambrey, submitted). The haematite which gives the reddish colour to the tillites is finely disseminated through the matrix, and petrographic studies suggest a secondary, probably diagenetic, origin. Possibly this haematite was formed by oxidation during burial of iron-magnesium minerals derived from igneous and metamorphic rocks which are well represented as stones in the tillite (Fairchild \& Hambrey, submitted). Petrographic studies are clearly essential if we are to understand the significance of these common Late Proterozoic associations.

Lastly I don't necessarily agree with Williams that there is an apparent preference of ice-sheets to form in low to moderate palaeolatitudes, and I would not rule out global glaciation. Varangian tillites are so widespread that it is difficult to place them all in such latitudes. For example, those in North Africa may have developed in high palaeolatitudes. In any case the area occupied by high latitudes is small, so this is likely to be reflected in the dominance of low-latitude tillites if indeed glaciation was global. But as Williams points out, we depend ultimately on accurate palaeomagnetic data. 